\title{
Microtubule-Associated Serine/Threonine-Protein Kinase 2
}

National Cancer Institute

\section{Source}

National Cancer Institute. Microtubule-Associated Serine/Threonine-Protein Kinase 2. NCI Thesaurus. Code C101460.

Microtubule-associated serine/threonine-protein kinase 2 (1798 aa, $196 \mathrm{kDa}$ ) is encoded by the human MAST 2 gene. This protein is involved in both cytoskeletal organization and protein phosphorylation. 